\title{
PENGARUH KOMUNIKASI PEMASARAN TERPADU DAN KOMITMEN TERHADAP LOYALITAS NASABAH
}

\author{
Valentine, Hasrul Siregar, Esty Pudyastuti \\ Sekolah Tinggi Ilmu Ekonomi IBBI
}

\begin{abstract}
ABSTRAK / ABSTRACT
Penelitian ini bertujuan untuk mengetahui pengaruh komunikasi pemasaran terpadu dan komitmen terhadap loyalitas nasabah deposito PT Bank DBS Indonesia.Metode penelitian yang digunakan adalah penelitian deskriptif kuantitatif.Teknik pengumpulan data dengan kuesioner.Populasi dan sampel dalam penelitian berjumlah 112 responden. Hasil pembahasan dijelaskan bahwa menunjukkan bahwa komunikasi pemasaran terpadu dan komitmen berpengaruh positif dan signifikan terhadap loyalitas nasabah deposito PT Bank DBS Indonesia. Besarnya koefisien determinasi Adjusted $R$ Square sebesar 0,266 artinya variabel independen yang terdiri dari komunikasi pemasaran terpadu dan komitmen dapat menjelaskan loyalitas nasabah sebesar 26,6\% dan sisanya $73,4 \%$ dijelaskan variabel lain yang tidak dimasukkan dalam model penelitian, seperti kualitas produk, citra merek, kualitas pelayanan dan sebagainya.
\end{abstract}

Kata Kunci :Komunikasi Pemasaran Terpadu, Komitmen, Loyalitas

This study aims to determine the effect of integrated marketing communication and commitment to customer loyalty deposits of PT Bank DBS Indonesia. The research method used is quantitative descriptive research. Data collection techniques with questionnaires. Population and sample in the study amounted to 112 respondents. The results of the discussion are explained that shows that integrated marketing communication and commitment have a positive and significant influence on customer loyalty deposits of PT Bank DBS Indonesia. The magnitude of the determination coefficient Adjusted $R$ Square of 0.266 means that the independent variable consisting of integrated marketing communication and commitment can explain customer loyalty by $26.6 \%$ and the remaining $73.4 \%$ explained other variables not included in the research model, such as product quality, brand image, quality of service and so on.

Keywords: Integrated Marketing Communication, Commitment, Loyalty 


\section{PENDAHULUAN}

Adanya kemajuan yang pesat pada perekonomian global dewasa ini, mendorong pertumbuhan pada sektor jasa.Salah satu sektor jasa di Indonesia yang telah mengalami kemajuan yang positif adalah sektor perbankan. Bank sebagai lembaga keuangan mempunyai peranan yang sangat penting di dalam masyarakat, di mana bank berperan dalam usaha perhimpunan dana maupun pengeluaran dana baik untuk perseorangan maupun perusahaan. Tujuan utama bank adalah guna menciptakan dan mempertahankan nasabah, baik nasabah perusahaan maupun nasabah perseorangan.Namun, terjadinya perubahan lingkungan yang cepat dalam berbagai hal seperti teknologi serta peraturan dan struktur, telah mengubah industri perbankan di seluruh dunia dan industri perbankan di Indonesia.Pada industri perbankan di Indonesia telah terjadi perubahan yang cukup menarik di mana terjadinya pergeseran bisnis perbankan, dari perbankan yang melayani perusahaan (corporate banking) menjadi perbankan yang lebih fokus melayani perseorangan (consumer banking).

Dalam menciptakan keunggulan bersaing dalam consumer banking atau pasar perseorangan tersebut, salah satu hal yang dapat dilakukan dan cukup efektif adalah dengan membina hubungan yang erat dengan para nasabah perseorangan. Dengan membina hubungan yang erat, maka perusahaan perbankan akan mengetahui apa saja yang diinginkan dan dibutuhkan oleh nasabah perseorangan tersebut. Dengan mengetahui kebutuhan dan keinginan para nasabah, nantinya perusahaan perbankan mampu memenuhi segala keinginan dan kebutuhan nasabah, sehingga akan tercipta kepuasan nasabah terhadap bank. Selain itu, membina hubungan yang erat dengan nasabah dalam jangka panjang secara terus-menerus, akan mampu mendorong pihak-pihak yang terlibat dalam hubungan menemukan caracara terbaik dalam berinteraksi sehingga nantinya diharapkan akan terciptanya kesetiaan nasabah. Bagi perusahaan perbankan, nasabah yang setia merupakan aset yang sangat berharga, karena selain mereka dapat menunjukkan citra perusahaan terhadap publik, mereka juga dapat meningkatkan profitabilitas bank. Selain itu nasabah yang setia atau nasabah yang loyal kepada perusahaan, akan mengurangi usaha perusahaan mencari nasabah baru dan memberikan umpan balik positif kepada perusahaan

Dalam kegiatan bisnis, komunikasi pemasaran menjadi sangat penting, dan merupakan bagian dari bauran pemasaran.Karena itu untuk mempertahankan pelanggan dan menarik pelanggan yang baru, perusahaan biasanya melakukan komunikasi pemasaran yang sesuai dengan karakter pelanggan sasarannya. Komunikasi pemasaran akan menentukan dampak pada loyalitas nasabah. Kegiatan promosi akan mendorong konsumen untuk melakukan pembelian ulang. Komunikasi pemasaran terintegrasi mengkoordinasikan dan 
mengintegrasikan semua elemen dari komunikasi pemasaran untuk memaksimalkan komunikasi pada konsumen dengan biaya yang relatif rendah. Komunikasi pemasaran terintegrasi merupakan integrasi dari komponennya, yang mencakup delapan hal, yaitu misi, target pasar, uang, media, pesan, bauran, pengukuran, dan pemasaran terhubung. Bauran merupakan gabungan dari alat promosi (yang di dalamnya ada iklan, penjualan pribadi, promosi penjualan, relasi publik, dan penjualan langsung).

Untuk mempertahankan hubungan jangka panjang yang bernilai dengan perusahaan alasan yang mendasari adalah tanpa ada komitmen nasabah yang tinggi maka akan sulit bagi perusahaan dalam mewujudkan loyalitas pelanggan. Disamping itu, komitmen nasabah memediasi pengaruh kepercayaan nasabah terhadap loyalitas nasabah.Kepercayaan nasabah yang tinggi menimbulkan komitmen dan selanjutnya berpengaruh terhadap loyalitas nasabah.

Didirikan pada 1989, dan menjadi bagian dari kelompok usaha DBS Group di Singapura, PT Bank DBS Indonesia (Bank DBS Indonesia) merupakan salah satu bank yang telah berdiri lama di Asia. Dengan 37 kantor cabang, 2 kantor kas dan 1.600 karyawan aktif di 13 kota besar di Indonesia, Bank DBS Indonesia menyediakan layanan perbankan menyeluruh untuk korporasi, usaha kecil dan menengah (SME), dan aktivitas perbankan konsumen. Diakui sebagai "Best Wealth Manager in Indonesia" oleh The Asset dan "Best Foreign Exchange Bank in Indonesia" oleh
Global Finance.DBS Indonesia juga merupakan penerima predikat 'Sangat Baik' untuk kategori Aset Rp50 Triliun sampai dengan di bawah Rp100 Triliun dari Infobank.Untuk berkontribusi lebih terhadap masyarakat, Bank DBS Indonesia turut mendorong pengembangan wirausaha sosial sebagai fokus area tanggung jawab sosial perusahaan.Berdasarkan wawancara yang dilakukan pada beberapa nasabah PT Bank DBS Indonesia bahwa pada perbankan ini terdapat penurunan loyalitas nasabah yang terlihat dari menurunnya jumlah nasabah dan sedikitnya yang menjadi nasabah baru pada perusahaan ini.

Tabel 1.1

Data Jumlah Nasabah Deposito Tahun 2013-2017

\begin{tabular}{|c|c|}
\hline Tahun & $\begin{array}{c}\text { Jumlah Nasabah } \\
\text { Deposito }\end{array}$ \\
\hline 2013 & 144 \\
\hline 2014 & 138 \\
\hline 2015 & 129 \\
\hline 2016 & 123 \\
\hline 2017 & 112 \\
\hline
\end{tabular}

Sumber :PT Bank DBS Indonesia, 2018

Tabel 1.1 terlihat bahwa jumlah nasabah deposito setiap tahunnya mengalami penurunan.Hal ini mencerminkan bahwa rendahnya loyalitas pelanggan despositoPT Bank DBS Indonesia.

Salah satu faktor yang diduga mengakibatkan penurunan loyalitas pelanggan adalah komunikasi pemasaran yang terpadu pada perbankan PT Bank DBS Indonesia. Sedikitnya melakukan kegiatan komunikasi pemasaran dan ketidaktertarikan nasabah terhadap komunikasi pemasaran yang 
diadakan pada perbankan ini serta sulitnya bersaing dengan perbankan lainnya dalam hal komunikasi pemasaran yang lebih menguntungkan nasabah, sedikitnya iklan-iklan yang dipromosikan untuk tabungan deposito sehingga banyak nasabah yang tidak mengetahui, personal selling atau staf marketing yang sedikit sehingga tidak dapat melakukan prospecting seluruh nasabah baru maupun lama dengan cepat dan kemudian kurangnya pelatihan yang diberikan kepada staf marketing baru mengenai produk desposito apa kelebihan manfaatnya dan kekurangannya sehingga penyampaian dengan nasabah tidak secara rinci sehingga menyebabkan banyaknya nasabah yang beralih ke bank yang lainnya, promosi penjualan yang sering tidak diadakan sehingga banyak nasabah yang pindah ke perbankan lainnya yang lebih menguntungkan.

Selain faktor komunikasi pemasaran, faktor komitmen juga diduga mempengaruhi penurunan loyalitas nasabah PT Bank DBS Indonesia.Komitmen pelanggan adalah keinginan pelanggan yang kuat untuk mempertahankan.Hubungan jangka panjang dengan pihak perusahaan.Permasalahan pada perbankan ini adalah kurangnya komitmen para nasabah sehingga tingkat kesetiaan nasabah yang rendah.Komitmen yang rendah dari nasabah disebabkan oleh ketidakramahan beberapa staf perbankan kepada nasabah sehingga menimbulkan ketidaksenangan dan kekecewaan.Sedikitnya nasabah yang mengunjungi perbankan ini kebanyakan nasabah hanya ingin dikunjungi by phone atau dilokasi yang ditentukan nasabah serta banyaknya nasabah yang tidak menginginkan perpanjangan kontrak.Ini menunjukkan bahwa terjadinya penurunan kesetiaan atau loyalitas nasabah pada perusahaan perbankan ini.

Berdasarkan uraian latar belakang tersebut diatas, maka peneliti tertarik dengan judul "Pengaruh Komunikasi Pemasaran Terpadu dan Komitmen terhadap Loyalitas Nasabah Deposito PT Bank DBS Indonesia."

\section{Kajian Pustaka}

Komunikasi Pemasaran Terpadu Menurut Kotler dan Keller (2015:172), Komunikasi pemasaran adalah sarana di mana perusahaan berusaha menginformasikan, membujuk dan mengingatkan konsumen secara langsung maupun tidak langsung tentang produk dan merek yang dijual.

Menurut Abdurrahman (2015:156), Komunikasi pemasaran atau promosi adalah salah satu bauran pemasaran yang digunakan untuk meningkatkan nilai pelanggan atau membangun ekuitas merek dalam ingatan pelanggan.

Menurut Ebert dan Griffin (2015:436), Promosi (promotion) merupakan teknik mengkomunikasikan informasi mengenai produk dan menjadi bagian dari bauran komunikasi, yaitu pesan keseluruhan yang dikirimkan perusahaan kepada pelanggan mengenai produknya."

Berdasarkan pengertian di atas, promosi merupakan suatu kegiatan komunikasi pemasaran yang 
menyebarkan informasi, mempengaruhi, membujuk, mengingatkan dan sebagainya untuk mendorong konsumen melakukan pembelian.

Indikator Komunikasi Pemasaran

Menurut Ebert dan Griffin (2015:437-443), Lima alat promosi yang paling berpengaruh dalam pemasaran adalah sebagai berikut :

1. Iklan

2. Penjualan personal (personal selling)

3. Promosi penjualan (sales promotion)

4. Pemasaran langsung atau interaktif(direct or interactive marketing)

5. Publitas dan hubungan masyarakat (publicity)

Komitmen

Menurut Tjiptono (2015:415) memberikan definisi komitmen adalah hasrat atau keinginan kuat untuk mempertahankan dan melanjutkan relasi yang dipandang penting dan bernilai jangka panjang.

Menurut (2012:129) mendefinisikan komitmen sebagai keinginan yang terus menerus untuk memelihara hubungan yang bernilai.

Menurut Barnes (2013:150) mendefinisikan komitmen adalah suatu keadaan psikologis seseorang yang secara global merasa ketergantungan pada suatu hubungan.

Menurut Nurdilek Dalziel (2012:128) Komitmen adalah tentang niat sadar yang dilakukan seseorang untuk menjaga hubungan jangka panjang
Berdasarkan beberapa definisi komitmen di atas, maka komitmen pelanggan yang dimaksud dalam penelitian adalah keinginan yang kuat yang tumbuh dari diri seseorang untuk mempertahankan hubungan jangka panjang yang bernilai dengan partner bisnisnya. Komitmen untuk tetap mempertahankan hubungan akan terbangun jika masing-masing pihak mendapatkan nilai yang diharapkan dari partner bisnisnya. Jika ada salah satu pihak yang merasa dirugikan maka tidak akan terwujud komitmen dalam jangka panjang.

\section{Indikator Komitmen} Menurut Endang (2012:324) komitmen nasabah pada diukur dengan tiga indikator yaitu :

1. Memiliki ikatan emosional

2. Rasa memiliki

3. Hubungan penting untuk dipertahankan.

Loyalitas Nasabah

Menurut

Yuniarti

(2015:241),Loyalitas merupakan besarnya konsumsi dan frekuensi pembelian yang dilakukan oleh seorang konsumen terhadap suatu perusahaan.

Menurut Hasan (2013:121) menjelaskan bahwa,Loyalitas pelanggan merupakan perilaku yang terkait dengan merek sebuah produk, termasuk kemungkinan memperbaharui kontrak merek di masa yang akan datang.

Menurut Sangadji dan Sopiah (2013:105), Loyalitas lebih ditujukan pada suatu perilaku, yang ditujukkan dengan pembelian rutin dan didasarkan pada unit pengambilan keputusan. 
Menurut Adam (2015:52), Loyalitas pelanggan lebih mengarah kepada perilaku yang ditunjukkan dengan pembelian rutin yang didasarkan pada unit pengambilan keputusan.

Dengan demikian dapat disimpulkan bahwa loyalitas pelanggan merupakan komitmen atau sikap pelanggan yang melakukan pembelian berulang secara konsisten terhadap suatu produk atau jasa.

Indikator Loyalitas Nasabab

Menurut Sangadji dan Sopiah (2013:115) untuk mengukur loyalitas diperlukan beberapa atribut, yaitu :

1. Mengatakan hal yang positif tentang perusahaan kepada orang lain.

2. Merekomendasikan perusahaan kepada orang lain yang meminta saran.

3. Mempertimbangkan bahwa perusahaan merupakan pilihan pertama ketika melakukan pembelian jasa.

4. Melakukan lebih banyak bisnis atau pembelian dengan perusahaan dalam beberapa tahun mendatang.

\section{Kerangka Pemikiran}

Loyalitas pelanggan merupakan perilaku yang terkait dengan merek sebuah produk, termasuk kemungkinan memperbaharui kontrak merek di masa yang akan datang.

Komunikasi pemasaran adalah sarana di mana perusahaan berusaha menginformasikan, membujuk dan mengingatkan konsumen secara langsung maupun tidak langsung tentang produk dan merek yang dijual.
Komitmen adalah hasrat atau keinginan kuat untuk mempertahankan dan melanjutkan relasi yang dipandang penting dan bernilai jangka panjang.

Berdasarkan uraian diatas dapat disimpulkan bahwa komunikasi pemasaran terpadu dan komitmen dipengaruhi oleh loyalitas nasabah.

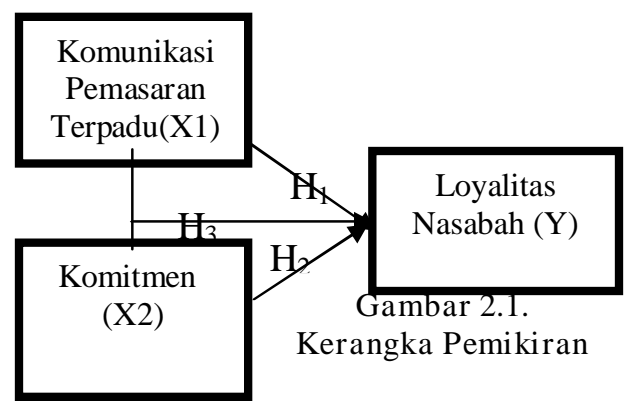

3.METODOLODI PENELITIAN

Populasi dan sampel dalam penelitian ini adalah sebanyak 112 nasabah deposito.Teknik analisis data yang digunakan adalah analisis regresi linear berganda setelah memenuhi asumsi klasik yang menyangkut uji normalitas, multikolinearitas, dan heterokedastisitas. Penarikan kesimpulan hipotesis dilakukan dengan cara uji t dan uji F pada level signifikansi $5 \%$. Keseluruhan tabulasi dan pengelolaan daa menggunakan software SPSS.

\section{HASIL PENELITIAN}

Hasil Uji Validitas

Hasil uji validitas dilakukan untuk mengetahui apakah instrumen dari penyataan yang digunakan valid dan dapat digunakan dalam penelitian ini.Hasil pengujian dengan membandingkan $r$ tabel terhadap $r$ hitung.Nilai $r$ hitung pada setiap pernyataan yang diuji lebih 
besar dari $r$ tabel, dapat disimpulkan bahwa pernyataan tersebut valid dan dapat digunakan dalam penelitian.

\section{Hasil Uji Reliabilitas}

Hasil uji reliabilitas digunakan untuk mengukur seberapa jauh konsisten alat ukur untuk dapat memberikan hasil yang sama dalam mengukur suatu hal yang sama. Hasil pengujian dengan melihat hasil nilai crobanch alpha harus lebih besar dari 0,60. Nilai crobanch alpha pada pernyataan yang ada menunjukkan hasil yang lebih besar dari 0,60 , maka penyataan yang digunakan dapat dikatakan reliabel.

Asumsi Klasik

Uji Normalitas

Berdasarkan grafik normal probability plot di atas menunjukkan bahwa semua data yang ada berdistribusi normal, karena semua data menyebar membentuk garis lurus diagonal maka data tersebut memenuhi asumsi normal atau mengikuti garis normalitas.

Pengujian normalitas data juga dilakukan dengan menggunakan alat uji statistik, yaitu uji Kolmogorov simorv menghasilkan nilai Asympy.Sig (2-tailed) sebesar 0,943di atas tingkat signifikan 0,05.

Uji Multikolinearitas

Uji multikolinearitas dilakukan untuk mengetahu.apakah terdapat hubungan linear antara variabel bebas. Untuk mengetahui ada tidaknya gejala multikolinearitas dapat dilihat dari besarnya nilai tolerance dan VIF (Variance Inflation Factor).masing-masing variabel bebas yang digunakan dalam penelitian ini memiliki nilai tolerance yang lebih besar dari 0,1 yaitu komunikasi pemasaran dan komitmen masing-masing sebesar 0,775. Jika dilihat dari VIF-nya, bahwa masing-masing variabel bebas lebih kecil dari 10 kepercayaan dan komitmen masing-masing sebesar 1,290. Dengan demikian, dapat disimpulkan bahwa tidak terjadi gejala multikolinearitas dalam variabel bebasnya..

\section{Uji Heterokedastisitas}

Grafik scatterplot terlihat bahwa titik-titik menyebar secara acak dengan tidak adanya pola yang jelas serta tersebar baik diatas maupun dibawah angka 0 pada sumbu Y. Dengan demikian, dapat disimpulkan bahwa tidak terjadi heterokedastisitas sehingga model ini layak dipakai untuk penelitian selanjutnya.

Berdasarkan pengujian glejser bahwa nilai sig kedua variabel adalah diatas 0,05 yaitu variabel komunikasi pemasaran sebesar 0,713 dan variabel komitmen sebesar 0,072. Dengan demikian, dapat disimpulkan bahwa tidak terjadi heterokedastisitas sehingga model ini layak dipakai untuk penelitian selanjutnya

Analisis Regresi Linear Berganda $\mathrm{Y}=5,090+0,273 \mathrm{X}_{1}+0,366 \mathrm{X}_{2}$

Penjelasan dari persamaan regresi berganda dalam penelitian adalah.

a. Dimana nilai konstanta ini menunjukkan bahwa apabila tidak terjadinya peningkatan sebesar satu satuan terhadap nilai variabel bebas yaitu komunikasi pemasarandan komitmen, maka perubahan loyalitas nasabah sebesar 5,590. 
b. Koefisien regresi ini menunjukkan bahwa setiap kenaikan komunikasi pemasaran sebesar satu satuan, maka loyalitas nasabah bertambah sebesar 0,273. Dengan asumsi variabel lain dianggap tetap.

Koefisien regresi ini menunjukkan bahwa setiap kenaikan komitmen sebesar satu satuan, maka loyalitas nasabah bertambah sebesar 0,366. Dengan asumsi variabel lain dianggap tetap.

Hasil Uji t
Uji
mengetahui $\begin{array}{r}\text { dilakukan } \\ \text { apakah }\end{array}$ independen dalam model regresi secara parsial berpengaruh terhadap variabel dependen.Berdasarkan hasil diatas dapat dilihat bahwa variabel komunikasi pemasaran terpadu memiliki nilai $t_{\text {hitung }}$ sebesar 2,821 lebih besar dari $t_{\text {tabel }}$ dsebesar 1,982 dan nilai signifikan t sebesar 0,006 lebih kecil dari 0,05 maka dapat disimpulkan bahwa $\mathrm{H}_{0}$ ditolak dan Ha diterima yaitu secara parsial komunikasi pemasaran terpadu berpengaruh positif dan signifikan terhadap Loyalitas Nasabah Deposito PT Bank DBS Indonesia.

Variabel komitmen memiliki nilai $t_{\text {hitung }}$ sebesar 3,813 lebih besar dari $t_{\text {tabelsebesar }} 1,982$ dan nilai signifikan t sebesar 0,000 lebih kecil dari 0,05 maka dapat disimpulkan bahwa $\mathrm{H}_{0}$ ditolak dan $\mathrm{Ha}$ diterima secara parsial komitmen berpengaruh positif dan signifikan terhadap Loyalitas Nasabah Deposito PT Bank DBS Indonesia.

Hasil Uji F

Hasil pengujian hipotesis secara simultan (uji F) bahwa nilai
$F_{\text {hitung }}$ sebesar 21,079> $F_{\text {tabel }}$ sebesar 3,08 dan nilai signifikan 0,000 lebih kecil dari 0,05, maka dapat disimpulkan bahwa $\mathrm{H}_{0}$ ditolak dan Ha diterima yaitu secara simultan Komunikasi Pemasaran Terpadu dan Komitmen berpengaruh positif dan signifikan terhadap Loyalitas Nasabah Deposito PT Bank DBS Indonesia.

\section{Hasil Koefisien Determinan}

Hasil koefisien determinasi dapat di lihat dari nilai Adjusted $R$ Square sebesar 0,266 artinya variabel independen yang terdiri dari komunikasi pemasaran terpadu dan komitmen dapat menjelaskan loyalitas nasabah sebesar 26,6\% dan sisanya $73,4 \%$ dijelaskan variabel lain yang tidak dimasukkan dalam model penelitian, seperti kualitas produk, citra merek, kualitas pelayanan dan sebagainya

Pembahasan

Pengaruh Komunikasi Pemasaran Terpadu Terhadap Loyalitas Nasabah

Berdasarkan pengujian secara parsial bahwa komunikasi pemasaran terpadu memiliki nilai $t_{\text {hitung }}$ sebesar 2,821 lebih besar dari $t_{\text {tabel }}$ dsebesar 1,982 dan nilai signifikan $t$ sebesar 0,006 lebih kecil dari 0,05 maka dapat disimpulkan bahwa secara parsial komunikasi pemasaran terpadu berpengaruh positif dan signifikan terhadap Loyalitas Nasabah Deposito PT Bank DBS Indonesia.

Hasil penelitian yang dilakukan oleh Limakrisna (2012) dijelaskan bahwa komunikasi pemasaran terpadu mempunyai 


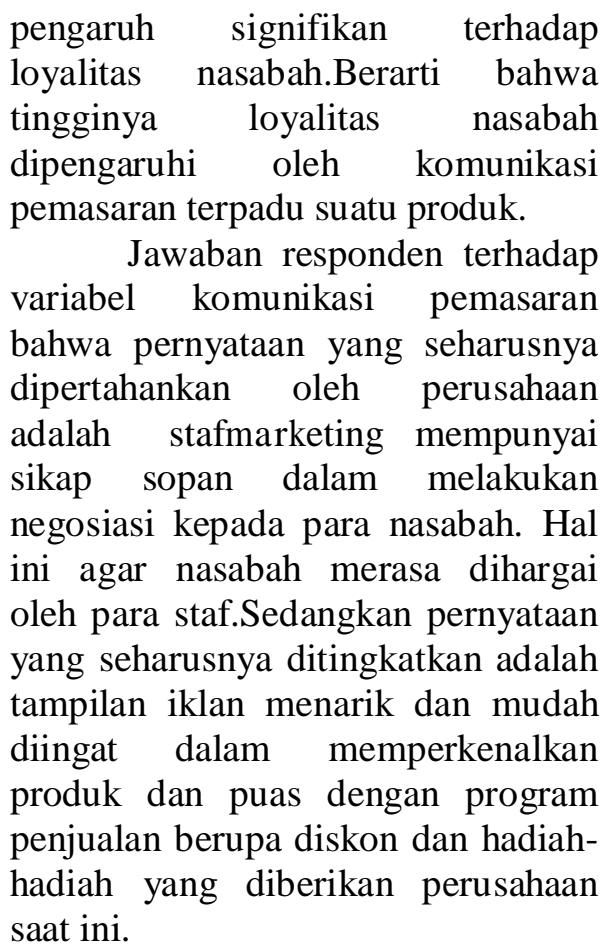

Sedikitnya melakukan

kegiatan komunikasi pemasaran dan

ketidaktertarikan nasabah terhadap komunikasi pemasaran yang diadakan pada perbankan ini serta sulitnya bersaing dengan perbankan lainnya dalam hal komunikasi pemasaran yang lebih menguntungkan nasabah, sedikitnya iklan-iklan yang dipromosikan untuk tabungan deposito sehingga banyak nasabah yang tidak mengetahui, personal selling atau staf marketing yang sedikit sehingga tidak dapat melakukan prospecting seluruh nasabah baru maupun lama dengan cepat dan kemudian kurangnya pelatihan yang diberikan kepada staf marketing baru mengenai produk desposito apa kelebihan manfaatnya dan kekurangannya sehingga penyampaian dengan nasabah tidak secara rinci sehingga menyebabkan banyaknya nasabah yang beralih ke bank yang lainnya, promosi penjualan yang sering tidak diadakan sehingga banyak nasabah yang pindah ke perbankan lainnya yang lebih menguntungkan.

Pengaruh Komitmen terhadap Loyalitas Nasabah

Variabel komitmen memiliki nilai $t_{\text {hitung }}$ sebesar 3,813 lebih besar dari $t_{\text {tabel }}$ sebesar 1,982 dan nilai signifikan t sebesar 0,000 lebih kecil dari 0,05 maka dapat disimpulkan secara parsial komitmen berpengaruh positif dan signifikan terhadap Loyalitas Nasabah Deposito PT Bank DBS Indonesia.

Hasil ini sejalan dengan penelitian yang dilakukan oleh Santi (2014) dijelaskan bahwa komitmen mempunyai pengaruh signifikan terhadap loyalitas nasabah. Berarti bahwa tingginya loyalitas nasabah dipengaruhi oleh komitmen suatu produk yang dilakukan oleh perusahaan.

Jawaban responden terhadap variabel komitmen bahwa kuesioner yang seharusnya di pertahankan adalah nasabah cocok dengan sistem pelayanan yang diberikan.Sedangkan kuesioner atau pernyataan yang seharusnya ditingkatkan adalah kenyamanam tingkat fasilitas yang ditawarkan dan tingkat kesetiaan nasabah yang tinggi pada perusahaan ini.

Komitmen pelanggan adalah keinginan pelanggan yang kuat untuk mempertahankan.Hubungan jangka panjang dengan pihak perusahaan.Permasalahan pada perbankan ini adalah kurangnya komitmen para nasabah sehingga tingkat kesetiaan nasabah yang rendah.Komitmen yang rendah dari nasabah disebabkan oleh 
ketidakramahan beberapa staf perbankan kepada nasabah sehingga menimbulkan ketidaksenangan dan kekecewaan.Sedikitnya nasabah yang mengunjungi perbankan ini kebanyakan nasabah hanya ingin dikunjungi by phone atau dilokasi yang ditentukan nasabah serta banyaknya nasabah yang tidak menginginkan perpanjangan kontrak.Ini menunjukkan bahwa terjadinya penurunan kesetiaan atau loyalitas nasabah pada perusahaan perbankan ini.

Pengaruh Komunikasi Pemasaran Terpadu dan Komitmen terhadap Loyalitas Nasabah

Berdasarkan pengujian secara simultan bahwa nilai $\mathrm{F}_{\text {hitung }}$ sebesar 21,079> $F_{\text {tabel }}$ sebesar 3,08 dan nilai signifikan 0,000 lebih kecil dari 0,05, maka dapat disimpulkan bahwa secara simultan Komunikasi Pemasaran Terpadu dan Komitmen berpengaruh positif dan signifikan terhadap Loyalitas Nasabah Deposito PT Bank DBS Indonesia.

Besarnya nilai koefisien determinasi yang didapat ialah nilai Adjusted $R$ Square sebesar 0,266 artinya variabel independen yang terdiri dari komunikasi pemasaran terpadu dan komitmen dapat menjelaskan loyalitas nasabah sebesar $26,6 \%$ dan sisanya $73,4 \%$ dijelaskan variabel lain yang tidak dimasukkan dalam model penelitian, seperti kualitas produk, citra merek, kualitas pelayanan dan sebagainya. Hasil penelitian ini konsisten dengan Antunes (2016) dijelaskan bahwa komunikasi pemasaran terpadu dan komitmen mempunyai pengaruh signifikan terhadap loyalitas nasabah.Berarti bahwa tingginya
Loyalitas nasabah dipengaruhi oleh komunikasi pemasaran terpadu dan komitmen penjualan suatu produk yang dilakukan oleh perusahaan.

\section{KESIMPULAN DAN SARAN}

Kesimpulan

Berdasarkan hasil pembahasan pada bab sebelumnya, maka dapat diambil beberapa kesimpulan sebagai berikut :

1. Berdasarkan pengujian secara parsial bahwa Komunikasi Pemasaran Terpadu berpengaruhpositif dan signifikan terhadap Loyalitas Nasabah Deposito PT Bank DBS Indonesia

2. Berdasarkan pengujian secara parsial bahwa Komitmen berpengaruhpositif dan signifikan terhadap Loyalitas Nasabah Deposito PT Bank DBS Indonesia

3. Berdasarkan pengujian secara simultan bahwa Komunikasi Pemasaran Terpadu dan Komitmen berpengaruhpositif dan signifikan terhadap Loyalitas Nasabah Deposito PT Bank DBS Indonesia.

Saran

Adapun saran dalam penelitian ini yaitu sebagai berikut :

1. Hal-hal yang seharusnya ditingkatkan mengenai

komunikasi pemasaran terpadu adalah tampilan iklan menarik dan mudah diingat dalam memperkenalkan produk dan puas dengan program penjualan berupa diskon dan hadiah-hadiah yang diberikan perusahaan saat ini.

2. Hal-hal yang seharusnya ditingkatkan mengenai komitmen 
adalah nasabah nyaman tingkat fasilitas yang ditawarkan dan tingkat kesetiaan nasabah belum tinggi.

3. Hal-hal yang seharusnya ditingkatkan mengenai loyalitas nasabah adalah nasabah bersedia untuk merekomendasikan kepada orang lain, nasabah setia dengan produk deposito yang ditawarkan sehingga melakukan perpanjangan apabila telah jatuh tempo dan nasabah tetap ingin melakukan perpajngan deposito dalam jangka panjang kepada perusahaan

\section{DAFTAR PUSTAKA}

Abdurrahman, Herdiana, Nana. 2015. Manajemen Strategi Pemasaran. Bandung : Pustaka Setia.

Adam, Muhammad. 2015. Manajemen Pemasaran Jasa Teori dan Aplikasi.Bandung : Alfabeta.

Antunes. 2016. The Effects of Trust, Commitment and Satisfaction onCustomer Loyalty in the Distribution Sector. International Business and ManagementISSN 1923-8428 (Online), Vol. 8, No. 2 pp 143-151, DOI 103968/4800.

Barnes, James G. 2013. Secrets Of Customer Relationship

Management.

ANDI,

Yogyakarta.

Ebert, Ronald, J dan Ricky W. Griffin. 2015. Pengantar Bisnis. Edisi Kesepuluh.
Jakarta : Gelora Aksara Pratama.

Endang Wijawan. 2012. Manajemen Pemasaran Teori dan Aplikasi.Bandung : Alfabeta.

Ghozali, Imam. 2013.Aplikasi Analisis Multivariate dengan Program IBM SPSS 23. Semarang : Universitas Diponegoro.

Hasan, Ali. 2013. Marketing dan Kasus-kasus Pilihan. Cetakan Kesatu. Yogyakarta : CAPS (Center for Academic Publishing Service).

Kotler, Philip dan Kevin Lane Keller. 2015. Manajemen Pemasaran. Pearson Education, inc.

Limakrisna.2012. Pengaruh Komunikasi Pemasaran dan Kerelasian Nasabah terhadap Loyalitas Nasbabah.Jurnal Analisis ISSN 1103-100X, Vol. 1 No. 1:51-57.

Nurdilek, Danzil. 2015. Manajemen Pemasaran. Jakartas : Rajawali Pers.

Priyatno, Duwi. 2014. SPSS 22: Pengolah Data Terpraktis. Yogyakarta: CV Andi Offset.

Sangadji, Mamang dan Etta Sopiah. 2013. Perilaku Konsumen Pendekatan Praktis Disertai Himpunan Jurnal Penelitian. Yogyakarta : Andi Offset.

Santi. 2014. Analisis Pengaruh Kualitas Produk, Komitmen Dan 
Kepercayaan Terhadap

Loyalitas Nasabah Giro Bank

Kalteng Cabang Utama

Palangka Raya. Jurnalanalisis

ISSN 2303-100X, Vol. 3 Np.

1:57-63.

Sanusi, Anwar. 2011. Metodologi Penelitian Bisnis : Disertai Contoh Proposal Penelitian Bidang Ilmu Ekonomi Dan Manajemen. Jakarta: Salemba Empat.

Sugiyono. 2012. Metode Penelitian Kuantitatif Kualitatif Dan $R \& D$. Bandung :PT Alfabeta.

Sunyoto. 2013. Teori, Kuesioner dan Analisi Data untuk Pemasaran dan Perilaku Konsumen. Center for Academic Publishing Service. Yogyakarta

Tjiptono, Fandy. 2008. Pemasaran Strategi. Edisi 2. Yogyakarta : ANDI OFFSET.

2015. Pemasaran Strategi. Edisi 4. Yogyakarta : ANDI OFFSET.

Moormat, wahyudi. 2012. Manajemen Pemasaran. Jakarta : Rajawali Pers.

Torang, Syamsir. 2016. Organisasi dan Manajemen (Perilaku, Struktur, Budaya dan Perubahan Organisai.Bandung : Alfabeta.

Yuniarti, Sri, Vinna. 2015. Perilaku
Konsumen Teori dan Praktek.Bandung : Pustaka Setia. 
